\title{
Borderline Papillary Mucinous Cystadenoma
}

National Cancer Institute

\section{Source}

National Cancer Institute. Borderline Papillary Mucinous Cystadenoma. NCI Thesaurus.

Code C4186.

A low malignant potential cystic epithelial neoplasm usually arising from the ovary. It is composed of glandular cells with intracytoplasmic mucin. It is characterized by an atypical epithelial proliferation and a papillary growth pattern. There is no evidence of destructive stromal invasion. 